\title{
Corn crop performance in an Ultisol compacted by tractor traffic
}

\author{
Moacir Tuzzin de Moraes(1), Renato Levien(2), Carlos Ricardo Trein ${ }^{(2)}$, \\ João de Andrade Bonetti( ${ }^{(3)}$ and Henrique Debiasi ${ }^{(4)}$
}

\begin{abstract}
(1)Universidade de São Paulo, Centro de Energia Nuclear na Agricultura, Avenida Centenário, no 303, São Dimas, CEP $13416-000$ Piracicaba, SP, Brazil. E-mail: moacir.tuzzin@gmail.com (2)Universidade Federal do Rio Grande do Sul, Faculdade de Agronomia, Departamento de Solos, Avenida Bento Gonçalves, № 7.712, CEP 91540-000 Porto Alegre, RS, Brazil. E-mail: renatole@gmail.com, trein@ufrgs.br ${ }^{(3)}$ Instituto Federal do Paraná, Campus Palmas, Avenida Bento Munhoz da Rocha Neto s/n, PRT-280 Trevo Codapar, CEP 8555-000 Palmas, PR, Brazil. E-mail: agro.bonetti@gmail.com ${ }^{(4)}$ Embrapa Soja, Rodovia Carlos João Strass, Distrito de Warta, CEP 86001-970 Londrina, PR, Brazil. E-mail: henrique.debiasi@embrapa.br
\end{abstract}

\begin{abstract}
The objective of this work was to determine whether compaction by tractor traffic in areas managed under controlled traffic can be limiting to corn crop, under different tillage systems, in a Typic Paleudult of medium texture. Two experiments were carried out, one in the field over two crop seasons and another in a greenhouse. The treatments consisted of minimum tillage with chiselling; no-tillage subjected to one, three, or six passes of a tractor weighing $3.8 \mathrm{Mg}$; and an area without traffic. Evaluations were performed for soil physicohydraulic parameters (soil bulk density, penetration resistance, and water retention curve), root and shoot growth, and grain yield. The agricultural traffic increased bulk density, soil penetration resistance, and water content at field capacity. The highest values for soil penetration resistance $(1,600 \mathrm{kPa})$ and bulk density $\left(1.67 \mathrm{~g} \mathrm{~cm}^{-3}\right)$ in the trafficked soil were not limiting to corn development and increased grain yield for both crop seasons. Tractor traffic of up to six passes is beneficial to corn cultivation, and it increases water availability and corn grain yield.
\end{abstract}

Index terms: Zea mays, grain yield, no-tillage, root growth, soil compaction.

\section{Desempenho da cultura do milho em Argissolo Vermelho compactado pelo tráfego agrícola}

\begin{abstract}
Resumo - O objetivo deste trabalho foi determinar se a compactação imposta pelo tráfego de trator, em áreas com tráfego controlado, pode ser limitante à cultura do milho em sistemas de preparo de um Argissolo Vermelho de textura média. Dois experimentos foram conduzidos, um no campo, em duas safras, e outro em casa de vegetação. Os tratamentos constituíram-se do uso de um sistema de preparo reduzido; um sistema plantio direto submetido a uma, três e seis passadas de trator de $3,8 \mathrm{Mg}$; e de uma área sem tráfego. Avaliaram-se os parâmetros físico-hídricos do solo (densidade do solo, resistência à penetração e curva de retenção de água), o crescimento radicular e da parte aérea, além da produtividade de grãos de milho. O tráfego agrícola incrementou os valores de densidade do solo e de resistência do solo à penetração, bem como o conteúdo de água do solo à capacidade de campo. Os máximos valores de resistência do solo à penetração $(1.600 \mathrm{kPa})$ e densidade do solo $\left(1,67 \mathrm{~g} \mathrm{~cm}^{-3}\right)$, nas parcelas trafegadas, não foram limitantes ao desenvolvimento do milho e incrementaram a produtividade de grãos em ambas as safras. $\mathrm{O}$ tráfego de até seis passadas com trator sobre a mesma área é benéfico à cultura de milho, e incrementa a disponibilidade de água e a produtividade de grãos de milho.
\end{abstract}

Termos para indexação: Zea mays, produtividade de grãos, sistema plantio direto, crescimento radicular, compactação do solo.

\section{Introduction}

No-tillage is a soil management system that aims at the sustainability of agroecosystems (Derpsch et al., 2010). Currently, more than 31.8 million hectares are already cultivated under this system in Brazil (Febrapdp, 2016), and more than 154 million hectares are managed under no-tillage worldwide (Calistru \& Jităreanu, 2014). However, the excessive agricultural traffic, associated with the absence of crop rotation, has led to the formation of compacted layers in the soil under no-tillage system (Franchini et al., 2012). The change of soil structure has led to degradation in several agricultural areas around the world, such as Australia (D'Emden et al., 2006), North America (Munkholm et al., 2013), Europe (López-Garrido et al., 2014), Asia (Singh et al., 2014), and South America (Moraes et al., 2016a).

In several places, techniques have been adopted to reduce the effects of machine traffic to avoid soil compaction. One example of these techniques is the use of controlled traffic (Gasso et al., 2013) 
by which agricultural machines travel in the same places to reduce the level of compaction in cultivated areas (McHugh et al., 2009), which has resulted in increased mean productivity of the areas (Tullberg et al., 2007). The main effects of soil compaction caused by excessive agricultural traffic are the increase of soil bulk density, soil penetration resistance and, consequently, the reduction of total porosity (McPhee et al., 2015), macroporosity (Dal Ferro et al., 2014), soil-water storage (Moraes et al., 2016a) and crop root growth (Bengough, 2012). However, it is not yet known whether agricultural traffic in sandy soils, which have a large volume of macropores, could be beneficial to plants by reducing pore size and altering water retention in these soils.

Soil compaction by agricultural traffic occurs with the first pass of the machine (Moraes et al., 2013); however, the greatest subsurface compaction problems caused by agricultural traffic are the result of the machines axle load (Keller et al., 2014), and by the accumulation of the number of passes over the same area (Moraes et al., 2013). Studies on controlled traffic to reduce the compaction levels of agricultural areas have been conducted in different soil types, such as in Latossolo Vermelho (Oxisol) in Brazil (Girardello et al., 2014), and in Australia (McPhee et al., 2015), where soils are clayey and highly susceptible to compaction by machine traffic (Moraes et al., 2013). However, there are few works undertaken in sandy soils that naturally have a high macroporosity (Mazurana et al., 2013), in which a possible reduction of aeration porosity would be beneficial to increase the amount of micropores responsible for water retention in the soil.

Therefore, the response of agricultural crops to soil physical conditions under no-tillage system is still not fully understood, which has led to discussions on the effects on crop productivity due to soil compaction.

The objective of this work was to determine whether compaction by tractor traffic in areas managed under controlled traffic can be limiting to corn cultivation in different tillage systems in a Typic Paleudult of medium texture.

\section{Materials and Methods}

Three experiments were carried out: two in two crop seasons (2013/2014 and 2014/2015) in the field, and one (2013/2014) under controlled conditions in a greenhouse, using undisturbed soil samples collected from the field.

The field experiment was conducted at the agricultural experiment station of Universidade Federal do Rio Grande do Sul $\left(30^{\circ} 06^{\prime} 30.3^{\prime \prime} \mathrm{S}, 51^{\circ} 40^{\prime} 35.8^{\prime \prime} \mathrm{W}\right.$, at $46 \mathrm{~m}$ altitude), located in the municipality of Eldorado do Sul, RS, Brazil. The soil of the region is classified as an Argissolo Vermelho distrófico (Santos et al., 2013), that is, a Typic Paleudult, of medium texture $\left(250 \mathrm{~g} \mathrm{~kg}^{-1}\right.$ clay, $200 \mathrm{~g} \mathrm{~kg}^{-1}$ silt, and $550 \mathrm{~g} \mathrm{~kg}^{-1}$ sand).

Implemented in 2008, the experiment had an experimental design with randomized complete blocks in bands, with a $2 \times 4$ factorial arrangement (tillage system $x$ traffic intensity), and three replicates. The plots were $15 \times 3.2 \mathrm{~m}$, and a crop rotation system was adopted, with clover and ryegrass in the winter and corn in the summer, controlled traffic of agricultural machinery, and different tillage systems. Controlled traffic consisted of concentrating tractor and sowing truck wheel tracks on the same area for all crops.

The factor tillage system consisted of no-tillage system (NT) and minimum tillage with soil chiselling (MTC), which was repeated in 2013, before the beginning of agricultural traffic. The factor traffic intensity was performed before corn cultivation, in the 2013/2014 season, and consisted of the following plots: no traffic (C0); one pass (C1); three passes (C3); and six passes (C6). A John Deere 5600 tractor of $3.8 \mathrm{Mg}$ was used, which had front tires 12.4-24 R1 and rear tires 18.4-30 R1, with inflation pressures of 95 and 110 $\mathrm{kPa}$. The tractor had a tire-soil contact area of $514 \mathrm{~cm}^{2}$ (front) and $1,018 \mathrm{~cm}^{2}$ (rear). The contact pressure of the front and rear tires with the soil were 115 and $120 \mathrm{kPa}$, respectively.

The determination of the soil physical properties was carried out in two periods (the 2013/2014 and $2014 / 2015$ crop seasons), at five soil depths (0-5, 5-10, $10-15,15-20$, and $20-25 \mathrm{~cm}$ ), which totalled 240 core soil samples (120 undisturbed samples per evaluation period). For both seasons, the undisturbed samples were collected in volumetric cylinders $(2.5 \mathrm{~cm}$ height, $6.3 \mathrm{~cm}$ diameter, and $78 \mathrm{~cm}^{3}$ volume) before corn was sown. In these undisturbed soil samples, the soil bulk density, total porosity, and the soil macroporosity and microporosity were determined. The sampling, in the two agricultural seasons (2013/2014 and 2014/2015), was conducted two days after a rainfall of $40 \mathrm{~mm}$, and the soil was considered to be at field capacity.

Pesq. agropec. bras., Brasília, v.53, n.4, p.464-477, Apr. 2018 DOI: 10.1590/S0100-204X2018000400008 
The undisturbed soil samples for each layer, for both crop seasons (2013/2014 and 2014/2015), were subjected to matric potentials of -6 and $-10 \mathrm{kPa}$ on a tension table, for the evaluations of soil macroporosity $(-6 \mathrm{kPa})$ and field capacity $(-10 \mathrm{kPa})$. The soil-water retention curve was measured using samples collected from the 5-10 cm soil depth, during the 2014/2015 crop season, subjected to the matric potentials of $-3,-6,-10$, $-33,-100$, and $-500 \mathrm{kPa}$. The water content retained at -1000 and $-1500 \mathrm{kPa}$ was determined using undisturbed samples and a dew point psychrometer (Water Potential Meter, model WP4-C). After mass determination, the soil samples were dried in an oven at $\pm 105^{\circ} \mathrm{C}$, for 24 hours, according to Claessen (1997).

Soil penetration resistance was determined during the 2013/2014 season, along a transect with five points in each plot, using an electromechanical penetrometer (Solotrack, Falker) with an automated soil insertion control rate, for the measurement and acquisition of data of the force applied to the respective soil depth. The soil-penetration resistance was determined down to $25 \mathrm{~cm}$ depth, with a measurement interval of $1 \mathrm{~cm}$. After data were collected, the mean soil-penetration resistance was calculated for $0-5,5-10,10-15,15-$ 20 , and $20-25-\mathrm{cm}$ soil depths. The soil-penetration resistance was performed together with the collection of undisturbed samples, and soil-water content was determined in the five layers down to $25 \mathrm{~cm}$.

Corn cultivar 30A77PW (Morgan) was cultivated in the field experiment in the 2013/2014 and 2014/2015 crop seasons. Corn sowing was executed by means of a tractor-pulled seed and fertilizer drill. Corn was sown in the first ten days of September at $0.05 \mathrm{~m}$ soil depth, using fertilizer roving rods acting at $0.12 \mathrm{~m}$ soil depth. Corn was harvested manually, by collecting the corn cobs along 24 linear meters $\left(10.8 \mathrm{~m}^{2}\right)$ in each plot, and threshed mechanically to allow of the cleaning and weighing of grains. Grain mass values were corrected for $13 \%$ moisture. Machine traffic-related spraying was performed in the area between the plots. The other mechanized operations were carried out under controlled traffic by which the passing of the tractor and combine harvester always occurred in the same regions within the plots.

In parallel, a study was carried out in a greenhouse, in which undisturbed soil samples collected from the field plots were used to analyze the initial development of corn under controlled soil moisture conditions.
The corn cultivar 30A77PW (Morgan) was cultivated for 32 days (phenological stage V6) in undisturbed soil samples collected during the 2013/2014 crop season from each of the experimental field plots. Twenty-four undisturbed soil samples were collected at 0-25 cm soil depth, in PVC tubes of $15 \mathrm{~cm}$ diameter and $25 \mathrm{~cm}$ height. During the sample collections, the PVC tubes were inserted vertically in the soil, using a hydraulic jack, and protected with a metallic structure according to the methodology described in Bortolon et al. (2009).

The undisturbed samples in PVC tubes, with an open bottom, were placed on sand in $10 \mathrm{~L}$ plastic pots $(25 \mathrm{~cm}$ high and $20 \mathrm{~cm}$ wide), so that the corn root system did not circle the pot and become root bound within the undisturbed soil sample.

In each tube, five corn seed were sown in $2.5 \mathrm{~cm}$ deep fissures, similarly to the way they were sown in the field. After emergence, only one seedling was left for each treatment, which was then cultivated for 32 days (V6 phenological stage), after which, the root and shoot parameters were evaluated. Plant height, stem diameter, and the dry mass of plant shoots were determined, as well as the fresh mass, dry mass, volume, surface area, diameter and the length of roots. The corn root system developed in the undisturbed soil inside the PVC tubes was washed with water (Böhm, 1979), using a set of 2, 1 , and $0.5 \mathrm{~mm}$ sieves. After root washing, $10 \%$ of the roots were sampled for image acquisition by a scanner and, subsequently, the volume, surface area, diameter, and length of roots were determined using the Safira software (Jorge \& Silva, 2010). The roots were then stained with methylene blue (1\% solution) for $15 \mathrm{~s}$ (Bodner et al., 2014), immersed in water, and scanned using a HP Scanjet 300 scanner, L2733A model.

Data from the experiments conducted in the field and in the greenhouse, when they conformed to the assumptions of the analysis of variance, were subjected to the F-test, at 5\% probability, and the effects of the significant interactions were determined. When the effects of the treatments were significant, the means were compared by the Tukey's test, at 5\% probability. The analyses were performed using the SAS software, version 8.0 (SAS Institute Inc., Cary, NC, USA).

\section{Results and Discussion}

Tractor traffic caused soil compaction in both tillage systems, down to $20 \mathrm{~cm}$ depth (Figure $1 \mathrm{~A}$ ), with 

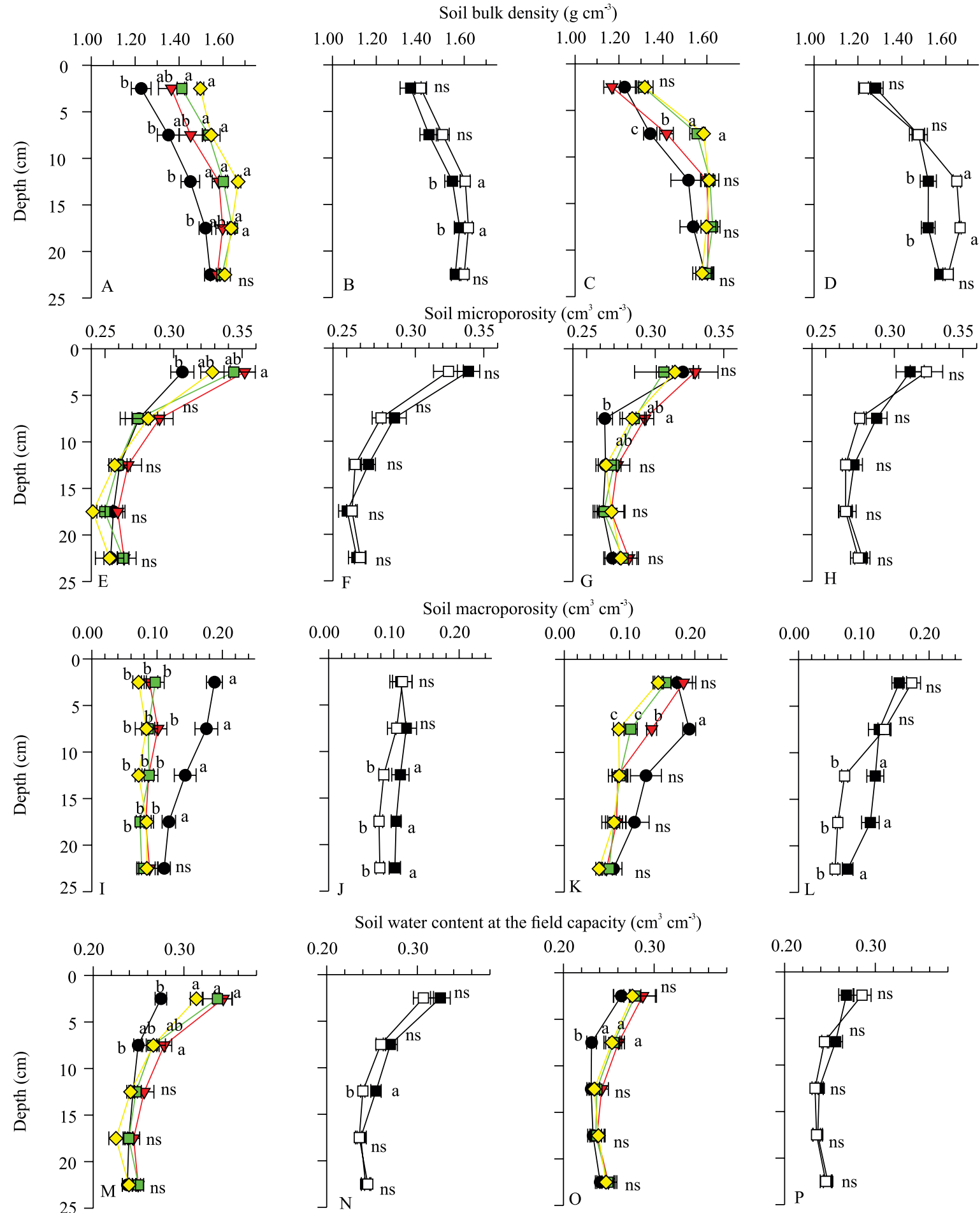

Soil water content at the field capacity $\left(\mathrm{cm}^{3} \mathrm{~cm}^{-3}\right)$

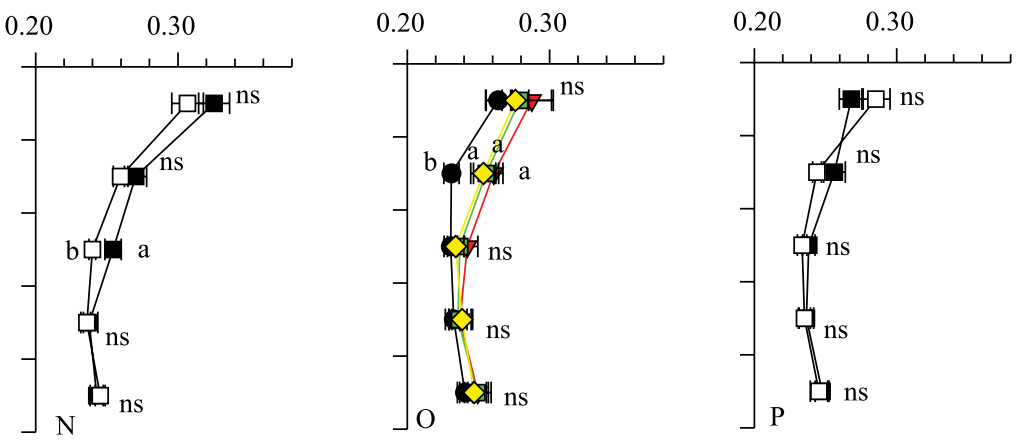

$$
\begin{array}{lllllllllll}
\hline- & \mathrm{C} 0 & \square & \mathrm{C} 3 & - & \mathrm{MTC} & \nabla & \mathrm{C} 1 & \diamond & \mathrm{C} 6 & \square
\end{array} \mathrm{NT}
$$

Figure 1. Soil bulk density (A-D), microporosity $(\mathrm{E}-\mathrm{H})$, macroporosity (I-L), and volumetric moisture at field capacity (M-P) as a function of the simple effect of traffic intensity and tillage system, in the 2013/2014 (A, B, E, F, I, J, M, and N) and 2014/2015 (C, D, G, H, K, L, O, and P) crop seasons, for five layers (0-25 cm) of a Typic Paleudult. C0, no traffic; C1, one tractor pass; $\mathrm{C} 3$, three tractor passes; and C6, six tractor passes. MTC, minimum tillage system with soil chiselling; and NT, no-tillage system. nsNonsignificant by the F-test, at 5\% probability. Means followed by equal letters for each soil layer do not differ from each other by the Tukey's test, at 5\% probability. 
three or six tractor passes favoring the transmission of tension, with significant increases of soil bulk density values in comparison to the site without traffic. The traffic in the chiselled plots increased the soil bulk density values, equaling those observed under no-tillage conditions (Figure $1 \mathrm{~B}$ ). At $20-25 \mathrm{~cm}$ soil depth, there was no change in the soil compaction level due to tractor traffic. One year after the traffic, significant effects were still found in the $5-10 \mathrm{~cm}$ layer (Figure $1 \mathrm{C}$ ), indicating that the traffic intensities affected the soil structure and could have contributed to the alteration of water and nutrient fluxes during the corn growing season.

Irrespectively of the tillage system (minimum tillage with chiselling and no-tillage), soil compaction levels increased due to the traffic increase (Figure $1 \mathrm{~A})$. One pass with the tractor was sufficient to match the soil bulk density values in the minimum tillage system with those found in the no-tillage system. This indicates that soil chiselling increases the soil susceptibility to compaction by agricultural traffic (Ortigara et al., 2015), and that, under these soil conditions and soil tillage systems, the effects of soil bulk density reduction by the chiselling operation are eliminated by the first tractor pass. This increase of soil bulk density values shows that agricultural traffic in chiselled soil can be detrimental to the soil structure (Moraes et al., 2013), instantly returning the soil to its compaction condition prior to chiselling (Moraes et al., 2016b).

The agricultural traffic on this Typic Paleudult caused the increase of soil bulk density (Figure 1 A-D) and soil-penetration resistance (Figure 2) values, while reducing soil macroporosity (Figure $1 \mathrm{I}-\mathrm{L}$ ). Soil-penetration resistance values indicated that the maximum depth of the transmission of tension through the soil profile by tractor traffic occurred at greater depths in the chiselled soil $(25 \mathrm{~cm})$ than in the notillage system $(10 \mathrm{~cm})$ (Figure 2). Tension transmission through the soil profile depends on factors related to the

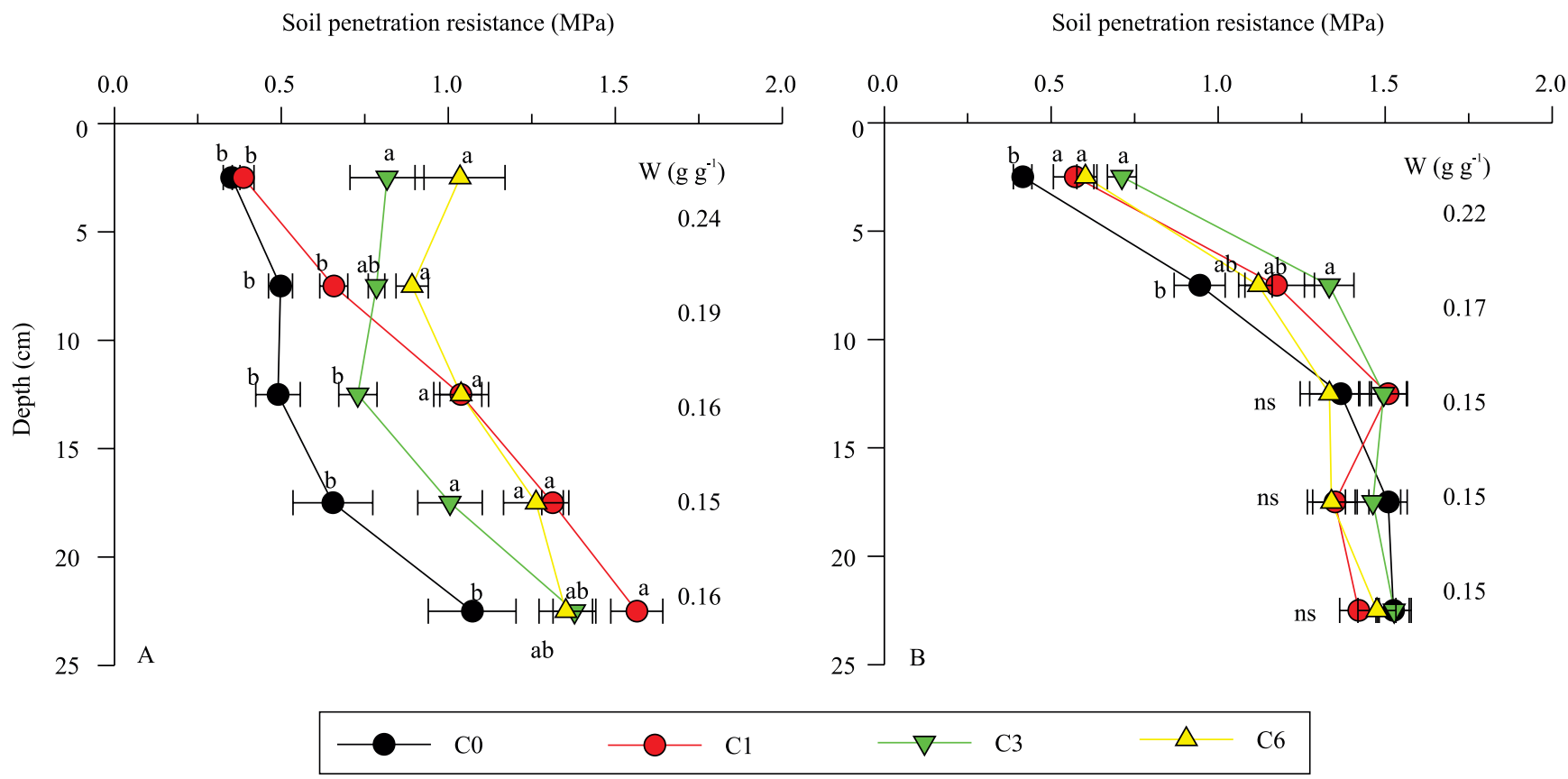

Figure 2. Soil penetration resistance as a function of the number of passes (traffic) and soil depth for minimum tillage with soil chiselling (A), and no-tillage system (B), in a Typic Paleudult in the 2013/2014 crop season. C0, no traffic; C1, one tractor pass; C3, three tractor passes; and C6, six tractor passes. W, soil-water content on a dry weight basis (g g-1). Means followed by equal letters in each soil layer do not differ from each other by the Tukey's test, at $5 \%$ probability. nsNonsignificant by the F-test, at 5\% probability. 
axle load of the equipment (Lamandé \& Schjønning, 2011a), the tire-ground contact pressure (Tolon Becerra et al., 2010), and on the number of machine passes (Moraes et al., 2013). In addition, the intensity of agricultural traffic-induced soil compaction is dependent on the degree of compaction (Moraes et al., 2013), water content (Lamandé \& Schjønning, 2011b), and mainly on the soil structure (Hamza \& Anderson, 2005) due to the lower stability of the connections between aggregates (Moraes et al., 2017), observed in the plots with chiselled soil, which indicates a lowerload support for machine traffic (Ortigara et al., 2015).

Tillage systems and traffic levels interactions in the soil layers indicate that the penetration resistance values were altered by the traffic of the tractor, in different ways, in the soil profile due to soil preparation (Figure 2 ). In the minimum tillage, there were alterations in the compaction levels throughout the profile $(0-$ $25 \mathrm{~cm}$ ), which happened as a result of the increased susceptibility of the chiselled soils to additional compaction by machine traffic (Ortigara et al., 2015). However, tension transmission by the agricultural traffic, in areas under no-tillage system in this Typic Paleudult, favored the compaction level increase only at $15 \mathrm{~cm}$ soil depth (Figure $2 \mathrm{~B}$ ), confirming that soils under no-tillage system show a greater resistance to compaction (Botta et al., 2010). This fact is indicative that the soil in the no-tillage system reduces tension transmission through the soil profile (Keller et al., 2014), maintaining the soil structure at pre-traffic compaction levels.

Irrespectively of the tillage system used, the water content at field capacity was altered as a function of the traffic intensity throughout the soil profile (Figure $1 \mathrm{M}-\mathrm{P})$. The agricultural traffic increased the amount of water stored in the soil, mainly until $10 \mathrm{~cm}$ soil depth, which can be attributed to the rearrangement of pores in the soil profile (Moraes et al., 2016a). In the $0-5 \mathrm{~cm}$ layer, the water content at field capacity in the plots with one tractor pass increased by $35 \%$ from $0.26 \mathrm{~cm}^{3} \mathrm{~cm}^{-3}$ (without traffic) to $0.35 \mathrm{~cm}^{3} \mathrm{~cm}^{-3}$, as a function of the increase of soil compaction level, and the consequent reduction of pore size (Moraes et al., 2016a), which favoured improvements in the water retention at more negative potentials (McHugh et al., 2009). This indicates that the traffic favoured increases of plant-available water capacity at $0-10 \mathrm{~cm}$ soil depth, mainly after the first pass of the $3.8 \mathrm{Mg}$ tractor, with a tire-ground contact pressure of $120 \mathrm{kPa}$. However, the increase of traffic intensity showed a tendency to reduce the water content at field capacity, but it was still higher than that of the traffic-free condition (Figure $1 \mathrm{M})$. Nonetheless, the effects of soil preparation systems were less prominent in the alteration of the water content at field capacity in the profile of this Typic Paleudult (Figure $1 \mathrm{~N}$ ).

In the 2014/2015 crop season, the water content retained at the matric potential of $-10 \mathrm{kPa}$ indicated that the residual effects of the agricultural traffic could still be observed at 5-10 $\mathrm{cm}$ soil depth (Figure $1 \mathrm{O}$ ). In this layer, the water content retained in the soil, in the plots with agricultural traffic, was higher than in the experimental units without traffic. The change of pore size distribution over time was reported by McHugh et al. (2009), who described the improvement of soil structural conditions over time through the use of notillage system and controlled traffic.

The change of soil-water retention was due mainly to the redistribution of the size of pores in the soil, which can be observed through the microporosity (Figure $1 \mathrm{E}-\mathrm{H}$ ) and soil macroporosity (Figure 1 I-L) values. Therefore, the greatest effects in relation to microporosity were observed in the $0-5 \mathrm{~cm}$ layer, where there were increases of the micropore volume in the plots with traffic compared with those without traffic (C0). After six tractor passes on this Typic Paleudult, it was possible to verify $5 \%$ increase of soil microporosity. In the second crop season (2014/2015), it was possible to observe the effects of the agricultural traffic on the 5-10 cm layer, in which there were increases of up to $4 \%$ in the plots with traffic compared with those without traffic.

The change of water content at field capacity (Figure $1 \mathrm{M}-\mathrm{P})$ was mainly due to the redistribution of the pore size (Figure $1 \mathrm{E}-\mathrm{L}$ ), which is in agreement with Moraes et al. (2016a). The increase of water retention can be explained by the volume reduction of the soil macropores, caused by the traffic on all layers between 0 and $25 \mathrm{~cm}$ depth (Figure $1 \mathrm{I}$ ). Therefore, soil physical conditions at the traffic sites indicate that there would be no physical degradation of the soil, as there is redistribution of soil pore size (McHugh et al., 2009), reducing the amount of macropores, which initially were excessive, favouring increases in the volume of pores that store water in the soil (micropores) (Moraes et al., 2016a).

Pesq. agropec. bras., Brasília, v.53, n.4, p.464-477, Apr. 2018 DOI: 10.1590/S0100-204X2018000400008 
The effects of the agricultural traffic were still observed in the 2014/2015 crop season, when larger volumes of macropores were found in the plots without traffic. The soil resilience processes due to wetting and drying cycles (Bonetti et al., 2017) provide an increase of the volume of macropores in previously compacted soils (Gregory et al., 2009), in the shortterm, which results in macropore values similar to those of plots without traffic. This indicates that, in the soil, the effects of the rearrangement of both particles and pores is constantly changing, tending to return to equilibrium if there are no new external disturbances (Todman et al., 2016).

The water retention curve of the soil was altered as a function of the agricultural traffic intensity (Figure 3 A), which was due to the alteration of pore size distribution, as reported by Moraes et al. (2016a). Soil total porosity, observed under saturated soil conditions in the water retention curve, indicates that there was a reduction of the total amount of soil pores in the
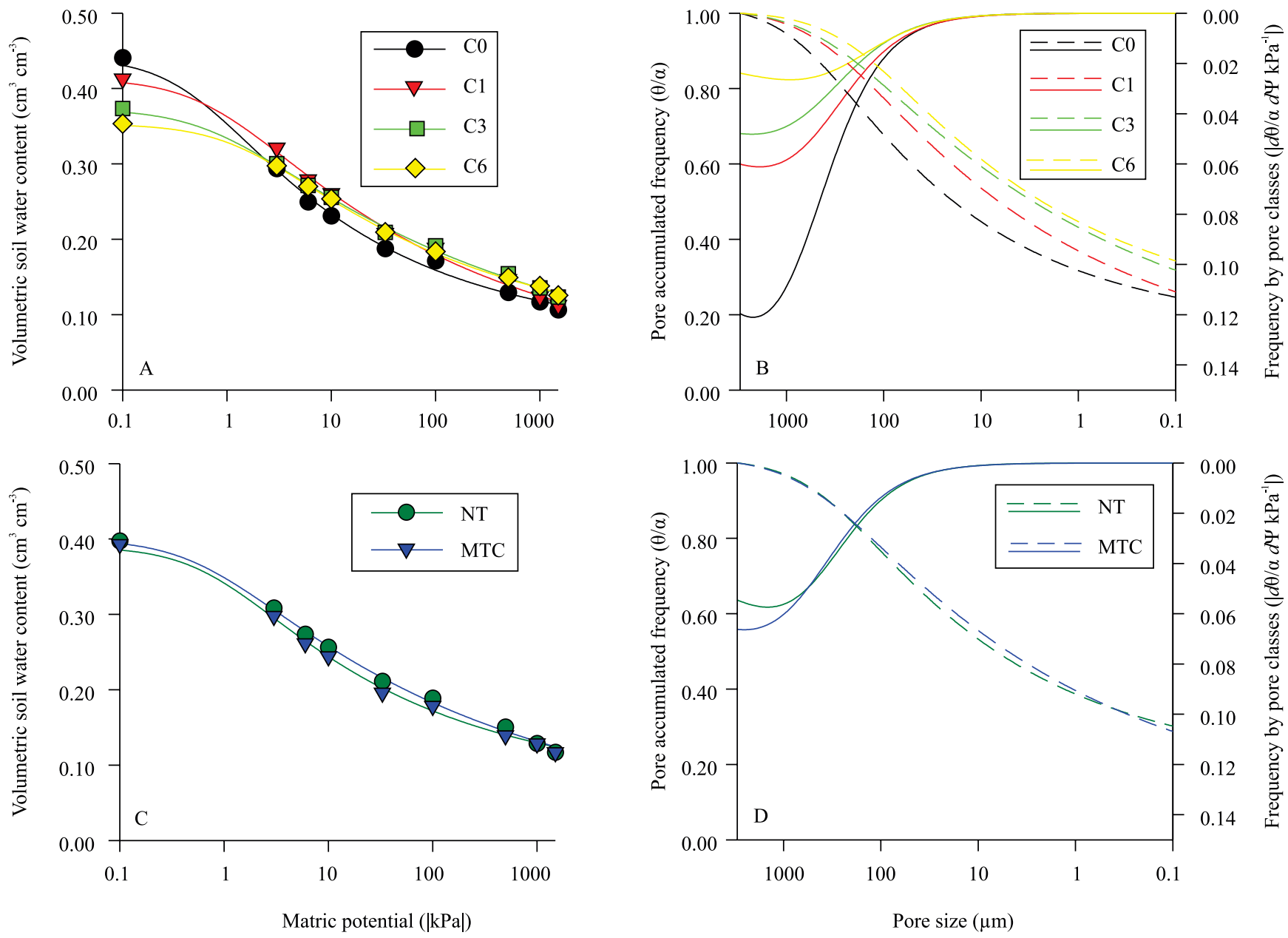

Figure 3. Soil-water retention curve (A and C) and pore size distribution and frequency (B and D), as a function of compaction level (A and B) and tillage system (C and D), at 5-10 cm soil depth of a Typic Paleudult, in the 2014/2015 crop season. C0, no traffic; $\mathrm{C} 1$, one tractor pass; $\mathrm{C}$, three tractor passes; and C6, six tractor passes. MTC, minimum tillage system with soil chiselling; and NT, no-tillage system. 
sequence $\mathrm{C} 0>\mathrm{Cl}>\mathrm{C} 3>\mathrm{C} 6$. However, under available water conditions for the crops between -6 and $-1,500$ $\mathrm{kPa}$, this sequence was inverted, and, for all the matric potentials, the lowest amount of water retained was observed in plots without traffic (C0). These changes indicate a higher-water availability in the plots with agricultural traffic, as a result of the change in the frequency of the pore size distribution (Figure 3 B). This shows that changes in pore geometry and higher-water availability under conditions of trafficked soil (McPhee et al., 2015) result in improvements in the physical conditions of this Typic Paleudult cropped with corn.

The soil preparation systems changed neither the water retention curve at $5-10 \mathrm{~cm}$ soil depth (Figure $3 \mathrm{C}$ ) nor the pore frequency nor the pore distribution of the soil (Figure 3 D). Therefore, the effects on the water retention in the soil were greater in comparison with the intensity of agricultural traffic than with the tillage systems. One year after the agricultural traffic, there were no alterations in the porous geometry, which resulted in similar water retention values between the chiselled soil and the plots under no-tillage system, indicating that the results agree with the short-term effect of soil chiselling, as reported for soils with clayey texture (Moraes et al., 2016a).

Tillage systems and traffic levels under greenhouse conditions with adequate water availability, during the development cycle, did not change the morphological parameters of shoots (stem diameter, plant height, and shoot dry mass) and roots (fresh mass, dry mass, volume, surface area, and diameter and length of roots)
(Table 1). This indicates that the observed soil bulk density values (Figure 1), as well as the soil-penetration resistance values (Figure 2), did not limit the shoot and root growth of corn in the soil. Thus, the increase of soil bulk density as a function of the agricultural traffic, in this Typic Paleudult, was neither considered as limiting to the growth of corn shoots and roots due the increase of soil-water storage in trafficked soil (Figure $1 \mathrm{M}-\mathrm{P}$ and Figure 3), which is important during periods with reduced rainfall. The maximum value for soil bulk density $\left(1.66 \mathrm{~g} \mathrm{~cm}^{-3}\right)$ in this Typic Paleudult was observed at $10-15 \mathrm{~cm}$ soil depth, in the plots with six tractor passes; however, this bulk density value was not limiting to corn root growth (Table 1).

The relationship of both bulk density (Figure 4) and soil-penetration resistance (Figure 5) with the corn morphological parameters indicates that there was no change for shoot growth as a function of soil bulk density (Figures 4 A, B, and C), nor soil penetration resistance (Figure $5 \mathrm{~A}, \mathrm{~B}$, and $\mathrm{C}$ ). The fresh root mass decreased with increasing soil bulk density (Figure 4 D), but it was not altered as a function of soil penetration resistance (Figure $5 \mathrm{D}$ ). In the minimum tillage system, there was a quadratic response of fresh root mass due to the increase of soil bulk density; the maximum quantity of roots was observed for $1.40 \mathrm{~g} \mathrm{~cm}^{-3}$ soil bulk density (Figure $4 \mathrm{D}$ ). Root dry mass and root diameter were not influenced by the soil bulk density (Figures 4 $\mathrm{E}$ and $\mathrm{F}$ ) nor by the soil penetration resistance (Figures $5 \mathrm{E}$ and $\mathrm{F}$ ).

The length, surface area and volume of roots, under both soil tillage systems, were reduced linearly as a

Table 1. Parameters for the development of the root system and shoot of corn (Zea mays), at 32 days after sowing, cultivated in undisturbed samples in a greenhouse, in comparison to soil preparation systems and traffic intensity in a Typic Paleudult.

\begin{tabular}{|c|c|c|c|c|c|c|c|c|c|}
\hline Treatment $^{(1)}$ & $\begin{array}{l}\text { Stem diameter } \\
(\mathrm{cm})\end{array}$ & $\begin{array}{l}\text { Plant height } \\
(\mathrm{cm})\end{array}$ & $\begin{array}{l}\text { Shoot dry } \\
\text { mass }(\mathrm{g})\end{array}$ & $\begin{array}{c}\text { Root fresh } \\
\text { mass }(\mathrm{g})\end{array}$ & $\begin{array}{l}\text { Root dry } \\
\text { mass }(\mathrm{g})\end{array}$ & $\begin{array}{l}\text { Root volume } \\
\left(\mathrm{dm}^{3} \mathrm{~cm}^{-3}\right)\end{array}$ & $\begin{array}{l}\text { Root surface } \\
\text { area }\left(\mathrm{cm}^{2} \mathrm{~cm}^{3}\right)\end{array}$ & $\begin{array}{l}\text { Root diameter } \\
(\mathrm{cm})\end{array}$ & $\begin{array}{c}\text { Root length } \\
\text { density }\left(\mathrm{cm} \mathrm{cm}^{-3}\right)\end{array}$ \\
\hline \multicolumn{10}{|c|}{ Tillage system } \\
\hline MTC & $18.2 \pm 0.7^{\mathrm{ns}}$ & $45.7 \pm 2.6^{\mathrm{ns}}$ & $16.1 \pm 3.9^{\mathrm{ns}}$ & $49.9 \pm 10.1^{\mathrm{ns}}$ & $3.32 \pm 0.8^{\mathrm{ns}}$ & $0.05 \pm 0.02^{\mathrm{ns}}$ & $1.51 \pm 0.50^{\mathrm{ns}}$ & $0.75 \pm 0.04^{\mathrm{ns}}$ & $0.54 \pm 0.17^{\mathrm{ns}}$ \\
\hline NT & $17.2 \pm 1.7$ & $44.8 \pm 2.3$ & $15.1 \pm 3.6$ & $42.2 \pm 5.8$ & $2.86 \pm 0.5$ & $0.04 \pm 0.01$ & $1.30 \pm 0.37$ & $0.77 \pm 0.05$ & $0.47 \pm 0.15$ \\
\hline \multicolumn{10}{|c|}{ Traffic intensity } \\
\hline $\mathrm{C} 0$ & $17.6 \pm 2.5^{\mathrm{ns}}$ & $44.3 \pm 2.3^{\text {ns }}$ & $16.2 \pm 3.9^{\mathrm{ns}}$ & $52.1 \pm 8.1^{\mathrm{ns}}$ & $3.36 \pm 0.6^{\mathrm{ns}}$ & $0.06 \pm 0.01^{\mathrm{ns}}$ & $1.75 \pm 0.43^{\mathrm{ns}}$ & $0.76 \pm 0.03^{\mathrm{ns}}$ & $0.62 \pm 0.16^{\mathrm{ns}}$ \\
\hline $\mathrm{C} 1$ & $17.8 \pm 0.8$ & $45.5 \pm 2.5$ & $15.5 \pm 4.5$ & $47.7 \pm 9.1$ & $3.35 \pm 1.1$ & $0.06 \pm 0.01$ & $1.76 \pm 0.30$ & $0.76 \pm 0.02$ & $0.62 \pm 0.09$ \\
\hline $\mathrm{C} 3$ & $18.0 \pm 1.0$ & $46.2 \pm 2.7$ & $15.8 \pm 3.9$ & $42.1 \pm 11.5$ & $2.59 \pm 0.7$ & $0.04 \pm 0.01$ & $1.17 \pm 0.35$ & $0.77 \pm 0.05$ & $0.43 \pm 0.14$ \\
\hline $\mathrm{C} 6$ & $17.6 \pm 1.0$ & $45.1 \pm 2.5$ & $15.1 \pm 3.6$ & $44.9 \pm 6.2$ & $3.25 \pm 0.4$ & $0.04 \pm 0.01$ & $1.10 \pm 0.31$ & $0.75 \pm 0.06$ & $0.41 \pm 0.13$ \\
\hline
\end{tabular}

${ }^{(1)}$ MTC, minimum tillage system with soil chiselling; NT, no-tillage system; C0, no traffic; C1, one tractor pass; C3, three tractor passes; and C6, six

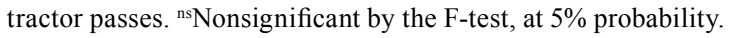


function of increasing soil bulk density (Figures 4 G, 4 H, 4 I); however, in the no-tillage system, these root parameters showed no relationship with soil penetration resistance (Figures $5 \mathrm{G}, \mathrm{H}$, and I). The reductions of root growth under the chiseled soil did not influence the corn shoot growth. This indicates that, even if there was a reduction of root growth in soil with traffic and in chiseled plots, the soil bulk density values that are limiting to shoot growth were not reached. Therefore, the maximum observed values for soil bulk density $\left(1.64 \mathrm{~g} \mathrm{~cm}^{-3}\right)$, and soil penetration resistance $(1500 \mathrm{kPa}$, determined with water content at
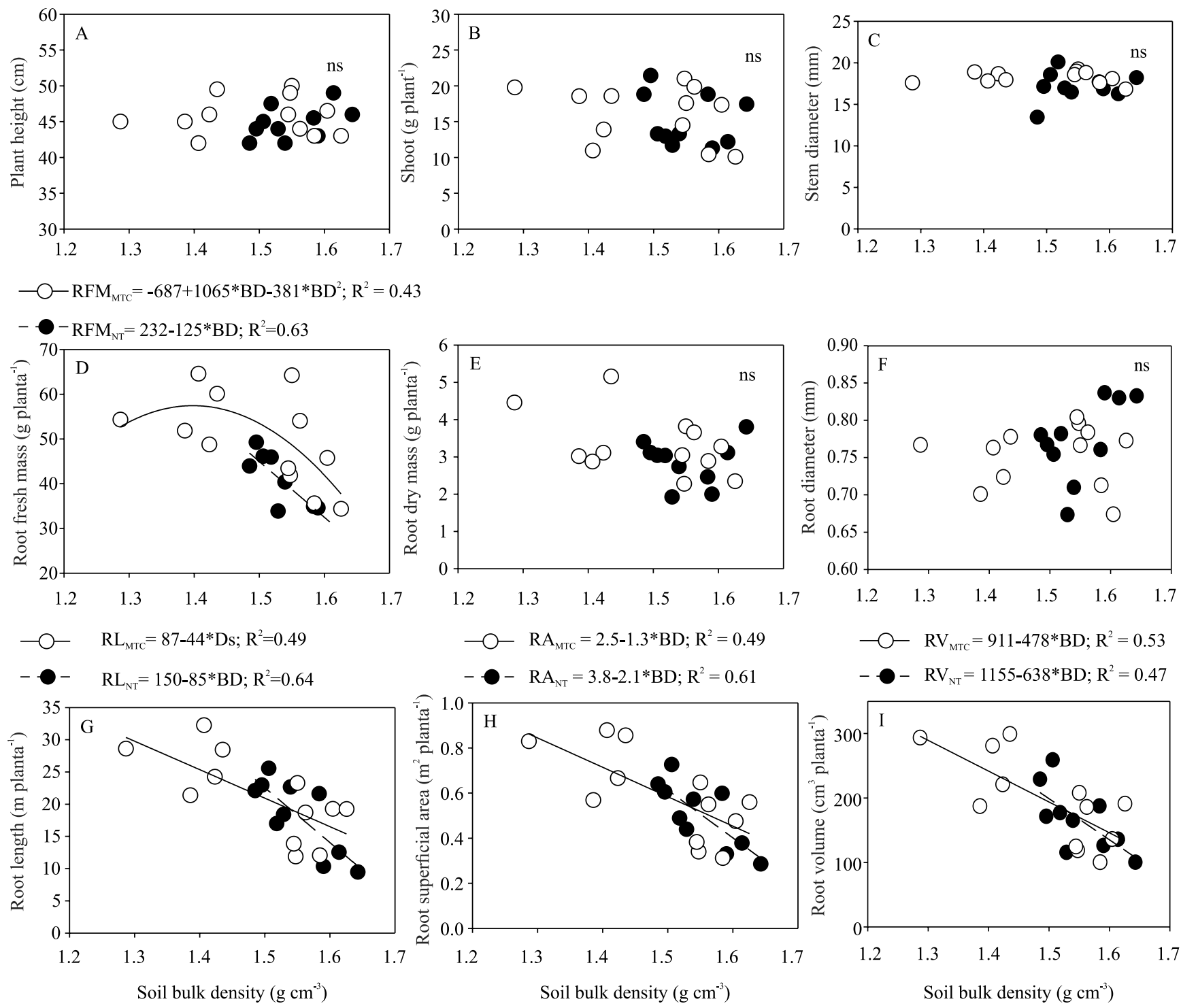

$-\mathrm{O}-\mathrm{MTC}-\bullet-\mathrm{NT}$

Figure 4. Relationship between the morphological parameters of corn (Zea mays) - plant height (A), shoot dry mass (B), stem diameter (C), root fresh mass (D), root dry mass (E), root diameter (F), root length $(\mathrm{G})$, root surface area $(\mathrm{H})$, and root volume (I) ᄀ- with soil bulk density at $0-25 \mathrm{~cm}$ soil depth of a Typic Paleudult under controlled traffic. MTC, minimum tillage system with soil chiselling; and NT, no-tillage system. nsNonsignificant by the F-test, at $5 \%$ probability. 
the field capacity) were not limiting to root and shoot growth in areas managed under soil chiseling, or notillage system, for corn grown under the absence of water restriction in a Typic Paleudult.

Root growth and shoot development (plant height, stem diameter and dry mass) obtained from undisturbed soil samples, and cultivated under water content at field capacity for 32 days of corn development (V6 stage), were not altered as a function of the tillage systems or agricultural traffic (Table 1). This evidences that for the studied compaction levels, associated with the absence of water stresses, the physical conditions of soil penetration resistance and aeration were not limiting to the growth and development of corn cultivated in this Typic Paleudult.

Corn grain yield was altered as a consequence of the traffic level and tillage system used (Figure 6). Short-term effects of chiseling of the Typic Paleudult
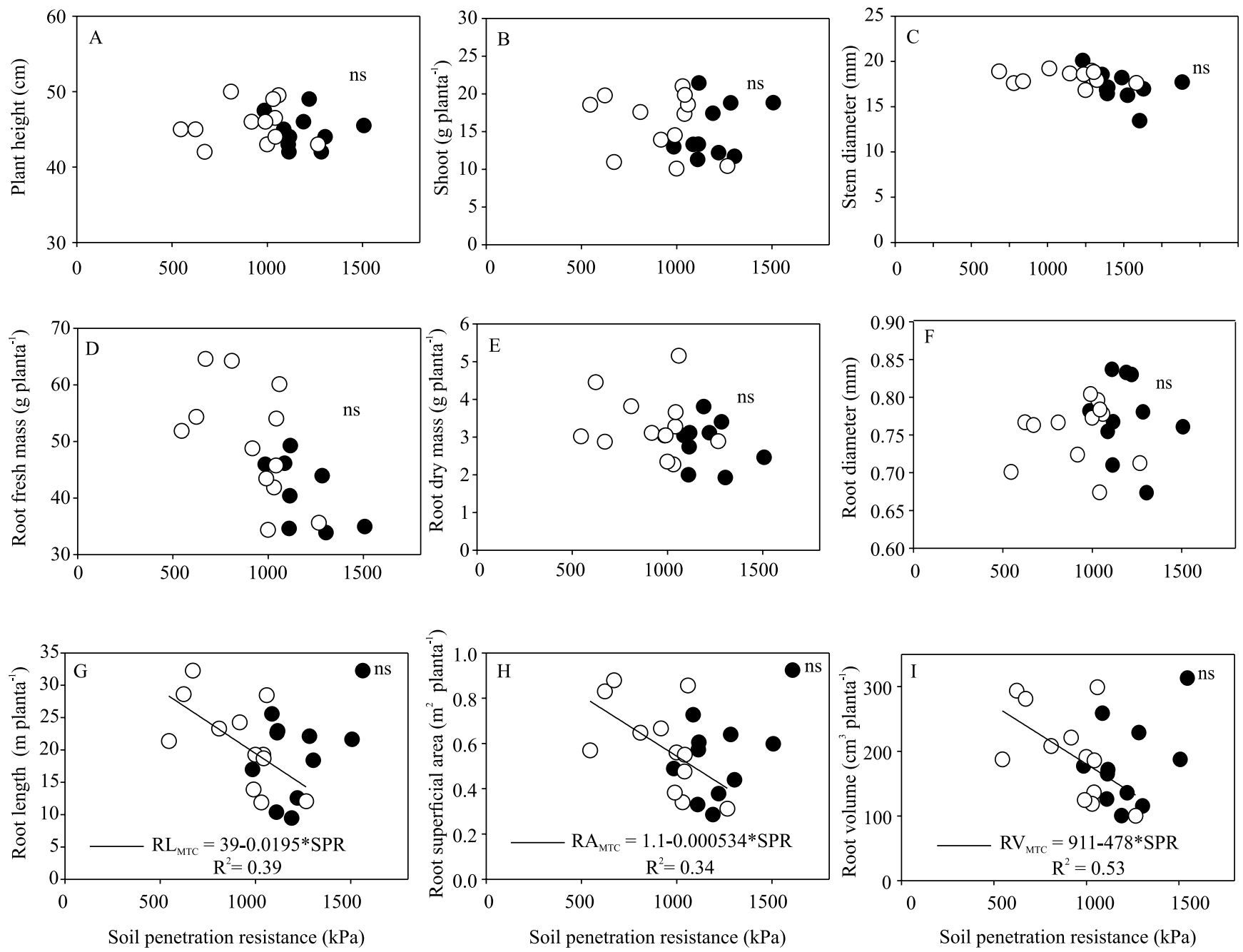

MTC

NT

Figure 5. Relationship between the morphological parameters of corn (Zea mays) - plant height (A), shoot dry mass (B), stem diameter $(\mathrm{C})$, root fresh mass $(\mathrm{D})$, root dry mass $(\mathrm{E})$, root diameter $(\mathrm{F})$, root length $(\mathrm{G})$, root surface area $(\mathrm{H})$, and root volume (I) - with soil penetration resistance at $0-25-\mathrm{cm}$ soil depth of a Typic Paleudult under controlled traffic. MTC, minimum tillage system with soil chiselling; and NT, no-tillage system. nsNonsignificant by the F-test, at $5 \%$ probability. 
on corn grain yield can be observed when comparing the grain production between areas with soil chiseling and no-tillage system in the crops of the 2013/2014 and 2014/2015 crop seasons (Figure 6). In the first cultivation after soil chiseling, in the 2013/2014 crop season (Figure $6 \mathrm{~A}$ ), corn grain yield in the chiseled and traffic-free soil was higher than in the area of notillage system without traffic. However, in the second year, in the 2014/2015 crop season, grain yield in the areas without traffic was the same for both the chiseled and no-tillage system areas (Figure 6 B). In addition, the experimental plots with traffic, under no-tillage or chiseled soil, showed higher corn grain yields in both the 2013/2014 (Figure 6 A) and 2014/2015 (Figure 6 B) crop seasons, and showed beneficial effects of soil particle rearrangement, providing increases of water availability in the soil, increasing the corn grain yield in the trafficked experimental plots.

The increase of corn grain yield under trafficked soil conditions indicates that corn was benefited by the changes in the soil physical and hydraulic conditions, which were improved as a function of agricultural traffic. The structural alteration of soil as a function of traffic with the tractor provided increases of the water content values at field capacity (Figures $1 \mathrm{M}-\mathrm{P}$ ), reducing the amount of macropores to values close to $10 \%$, altering the distribution frequency of the pores and the water retention curves of the soil (Figures 1 I-L). This indicates that corn response as a consequence of the increase of soil compaction is not always negative. Corn productive performance depends on the climatic conditions during the development cycle.

The increase of grain yield even with soil compaction (Figure 6) have a direct relationship with the soil-water availability in the plots with traffic because, in these areas, there was an increase in the availability of water to the plants, due to the increase of water content at the upper limit of water availability (Lindstrom \& Voorhees, 1994). Additionally, there was also a macroporosity reduction (Figure $1 \mathrm{I}-\mathrm{L}$ )
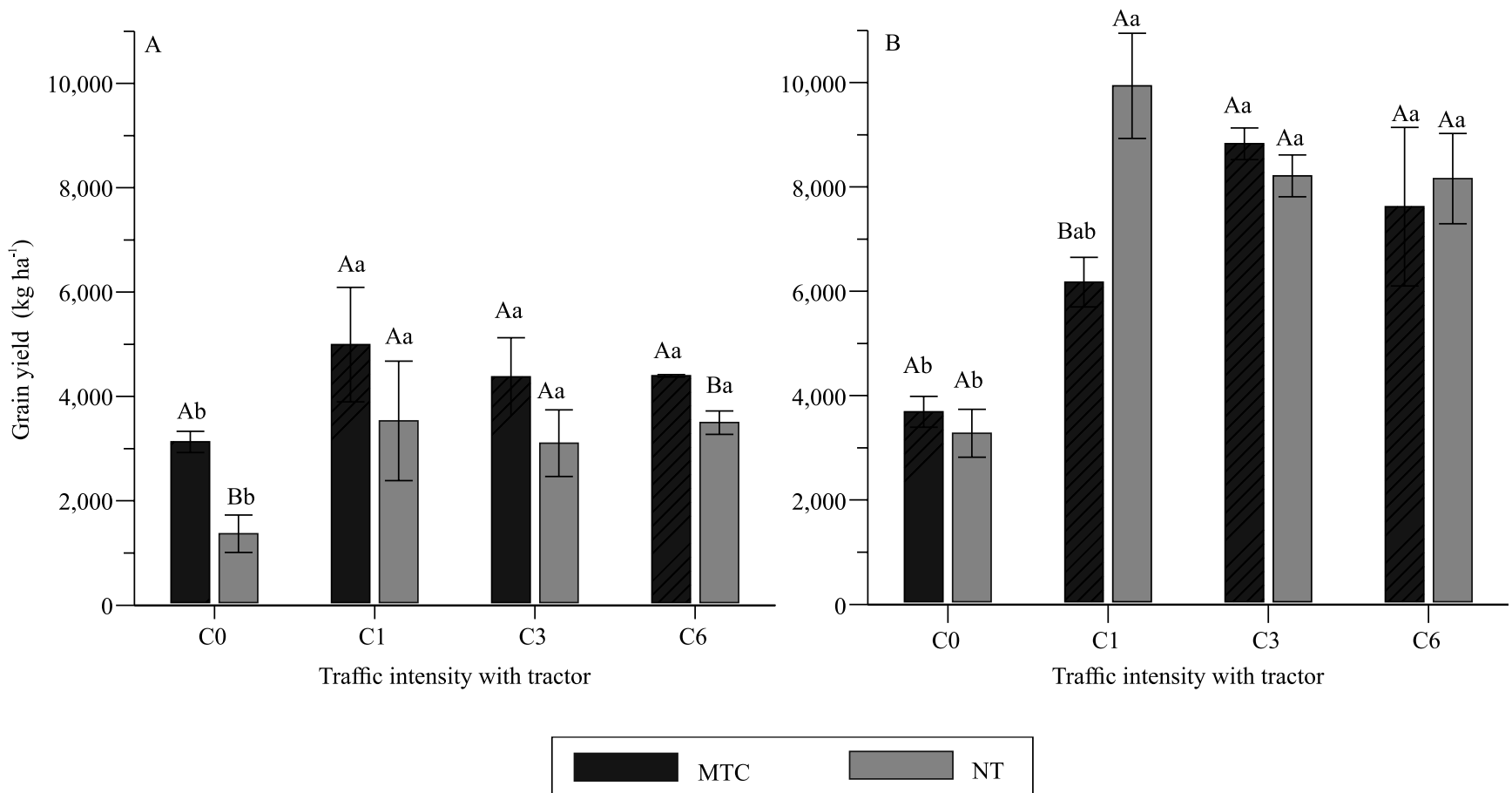

Figura 6. Corn (Zea mays) grain yield as a function of traffic intensity and tillage system on a Typic Paleudult, in the 2013/2014 (A) and 2014/2015 (B) crop seasons. C0, no traffic; C1, one tractor pass; C3, three tractor passes; and C6, six tractor passes. MTC, minimum tillage system with soil chiselling; and NT, no-tillage system. *Error bars indicate the standard error of the mean. Means followed by equal letters, uppercase between preparation systems and lowercase between traffic intensities, do not differ by the Tukey's test, at 5\% probability. 
with alterations in the pore distribution frequency of the soil-water retention curves (Figure 3). This can be attributed mainly to an increase of the seed-soil contact to allow seedling emergence (Lindstrom \& Voorhees, 1994), and to soil-root contact, with root diameter reduction, as a result of the root confinement in the pores (Jin et al., 2013).

In the plots with higher compaction levels, the diameter of soil pores was smaller (Figure 3) and, considering that the root elongation rate is only affected when mechanical stresses are applied to the root apex (axial pressures) (Bengough, 2012), the root diameter will be smaller, allowing of increases in the root surface area and, consequently, increases in root-water absorption rates (Nosalewicz \& Lipiec, 2014). This fact indicates that in areas with greater compaction levels, but with pore continuity in the soil profile, root growth is not reduced (Table 1), and there may still be increases in the root-soil contact that will favor the uptake of water by the roots.

The increase of soil compaction levels, caused by tractor traffic, increased water availability under unsaturated soil conditions mainly due to the increase of unsaturated hydraulic conductivity (Richard et al., 2001). Additionally, in the region of the rhizosphere, this conductivity is higher than the soil average (Carminati \& Vetterlein, 2013), and it occurs because of the presence of root mucilage (Carminati et al., 2011), which favors the water flow from the soil to the roots under low-water availability conditions (Carminati \& Vetterlein, 2013). Therefore, the rate of water absorption by the roots is directly related to the root surface area and, consequently, to root diameter and length.

\section{Conclusions}

1. Soil compaction increase - caused by tractor traffic, with a tire-soil contact pressure of $120 \mathrm{kPa}$, up to the studied level of six passes - improves the physical quality of the medium-textured Typic Paleudult, irrespectively of the soil tillage system employed.

2. Tractor traffic in the medium-textured Typic Paleudult increases the water content at field capacity, does not restrict the growth of shoots and roots of corn, and increases corn grain yield in comparison to plots without tractor traffic.

\section{Acknowledgments}

To Coordenação de Aperfeiçoamento de Pessoal de Nível Superior (Capes), for scholarship granted; to Universidade Federal do Rio Grande do Sul, for providing access to both the agricultural experiment station and the equipment to carry out the experiment; and to Fundação Agrisus (PA n ${ }^{\circ}$ 1236/13), for financial support.

\section{References}

BENGOUGH, A.G. Root elongation is restricted by axial but not by radial pressures: so what happens in field soil? Plant and Soil, v.360, p.15-18, 2012. DOI: 10.1007/s11104-012-1428-8.

BODNER, G.; LEITNER, D.; KAUL, H.-P. Coarse and fine root plants affect pore size distributions differently. Plant and Soil, v.380, p.133-151, 2014. DOI: 10.1007/s11104-014-2079-8.

BÖHM, W. Methods of studying root systems. Berlin: SpringerVerlag, 1979. (Ecological Studies, 33). DOI: 10.1007/978-3-64267282-8.

BONETTI, J. de A.; ANGHINONI, I.; MORAES, M.T. de; FINK, J.R. Resilience of soils with different texture, mineralogy and organic matter under long-term conservation systems. Soil and Tillage Research, v.174, p.104-112, 2017. DOI: 10.1016/j. still.2017.06.008.

BORTOLON, L.; GIANELlO, C.; CONTE, O.; OLIVEIRA, E.S.; LEVIEN, R. Equipamento para coleta de amostras indeformadas de solo para estudos em condições controladas. Revista Brasileira de Ciência do Solo, v.33, p.1929-1934, 2009. DOI: 10.1590/S0100-06832009000600042.

BOTTA, G.F.; TOLON-BECERRA, A.; LASTRA-BRAVO, X.; TOURN, M. Tillage and traffic effects (planters and tractors) on soil compaction and soybean (Glycine max L.) yields in Argentinean pampas. Soil and Tillage Research, v.110, p.167174, 2010. DOI: 10.1016/j.still.2010.07.001.

CALISTRU, A.E.; JITĂREANU, G. No-tillage around the world. Revista Lucrari Stiintifice. Seria Agronomie, v.57, p.11-15, 2014.

CARMINATI, A.; SCHNEIDER, C.L.; MORADI, A.B.; ZAREBANADKOUKI, M.; VETTERLEIN, D.; VOGEL, H.-J.; HILDEBRANDT, A.; WELLER, U.; SCHÜLER, L.; OSWALD, S.E. How the rhizosphere may favor water availability to roots. Vadose Zone Journal, v.10, p.988-998, 2011. DOI: 10.2136/ vzj2010.0113.

CARMINATI, A.; VETTERLEIN, D. Plasticity of rhizosphere hydraulic properties as a key for efficient utilization of scarce resources. Annals of Botany, v.112, p.277-290, 2013. DOI: $10.1093 / \mathrm{aob} / \mathrm{mcs} 262$.

CLAESSEN, M.E.C. (Org.). Manual de métodos de ánalise de solo. 2.ed. rev. e atual. Rio de Janeiro: EMBRAPA-CNPS, 1997. 212p. (EMBRAPA-CNPS. Documentos, 1).

Pesq. agropec. bras., Brasília, v.53, n.4, p.464-477, Apr. 2018 DOI: $10.1590 / \mathrm{S} 0100-204 X 2018000400008$ 
D'EMDEN, F.H.; LLEWELLYN, R.S.; BURTON, M.P. Adoption of conservation tillage in Australian cropping regions: an application of duration analysis. Technological Forecasting and Social Change, v.73, p.630-647, 2006. DOI: 10.1016/j. techfore.2005.07.003.

DAL FERRO, N.; SARTORI, L.; SIMONETTI, G.; BERTI, A.; MORARI, F. Soil macro- and microstructure as affected by different tillage systems and their effects on maize root growth. Soil and Tillage Research, v.140, p.55-65, 2014. DOI: 10.1016/j. still.2014.02.003.

DERPSCH, R.; FRIEDRICH, T.; KASSAM, A.; HONGWEN, L. Current status of adoption of no-till farming in the world and some of its main benefits. International Journal of Agricultural and Biological Engineering, v.3, p.1-25, 2010. DOI: 10.3965/j. issn.1934-6344.2010.01.0-0.

FEBRAPDP. Federação Brasileira de Plantio Direto e Irrigação. Sistema plantio direto. Available at: $<$ http://www.febrapdp.org. br>. Accessed on: Dec. 282016.

FRANCHINI, J.C.; DEBIASI, H.; BALBINOT JUNIOR, A.A.; TONON, B.C.; FARIAS, J.R.B.; OLIVEIRA, M.C.N. de; TORRES, E. Evolution of crop yields in different tillage and cropping systems over two decades in southern Brazil. Field Crops Research, v.137, p.178-185, 2012. DOI: 10.1016/j. fcr.2012.09.003.

GASSO, V.; SØRENSEN, C.A.G.; OUDSHOORN, F.W.; GREEN, O. Controlled traffic farming: a review of the environmental impacts. European Journal of Agronomy, v.48, p.66-73, 2013. DOI: 10.1016/j.eja.2013.02.002.

GIRARDELlO, V.; AMADO, T.; ERTEL, C.; GARLET, L. Benefícios do tráfego controlado de máquinas. A Granja, ed.785, p.34-37, 2014.

GREGORY, A.S.; WATTS, C.W.; GRIFFITHS, B.S.; HALLETT, P.D.; KUAN, H.L.; WHITMORE, A.P. The effect of long-term soil management on the physical and biological resilience of a range of arable and grassland soils in England. Geoderma, v.153, p.172-185, 2009. DOI: 10.1016/j.geoderma.2009.08.002.

HAMZA, M.A.; ANDERSON, W.K. Soil compaction in cropping systems: a review of the nature, causes and possible solutions. Soil and Tillage Research, v.82, p.121-145, 2005. DOI: 10.1016/j. still.2004.08.009.

JIN, K.; SHEN, J.; ASHTON, R.W.; DODD, I.C.; PARRY, M.A.J.; WHALLEY, W.R. How do roots elongate in a structured soil? Journal of Experimental Botany, v.64, p.4761-4777, 2013. DOI: $10.1093 /$ jxb/ert286.

JORGE, L.A. de C.; SILVA, D.J. da C.B. Safira: manual de utilização. São Carlos: Embrapa Instrumentação, 2010.

KELLER, T.; BERLI, M.; RUIZ, S.; LAMANDÉ, M.; ARVIDSSON, J.; SCHJØNNING, P.; SELVADURAI, A.P.S. Transmission of vertical soil stress under agricultural tyres: comparing measurements with simulations. Soil and Tillage Research, v.140, p.106-117, 2014. DOI: 10.1016/j.still.2014.03.001.

LAMANDÉ, M.; SCHJØNNING, P. Transmission of vertical stress in a real soil profile. Part II: Effect of tyre size, inflation pressure and wheel load. Soil and Tillage Research, v.114, p.7177, 2011a. DOI: 10.1016/j.still.2010.08.011.

LAMANDÉ, M.; SCHJØNNING, P. Transmission of vertical stress in a real soil profile. Part III: Effect of soil water content. Soil and Tillage Research, v.114, p.78-85, 2011b. DOI: 10.1016/j. still.2010.10.001.

LINDSTROM, M.J.; VOORHEES, W.B. Responses of temperate crops in North America to soil compaction. In: SOANE, B.D. OUWERKERK, C. van (Ed.). Soil Compaction in Crop Production. Amsterdam: Elsevier, 1994. p.265-286. (Developments in Agricultural Engineering, 11). DOI: 10.1016/ B978-0-444-88286-8.50020-9.

LÓPEZ-GARRIDO, R.; MADEJÓN, E.; LEÓN-CAMACHO, M.; GIRÓN, I.; MORENO, F.; MURILLO, J.M. Reduced tillage as an alternative to no-tillage under Mediterranean conditions: a case study. Soil and Tillage Research, v.140, p.40-47, 2014. DOI: 10.1016/j.still.2014.02.008.

MAZURANA, M.; FINK, J.R.; SILVEIRA, V.H. da; LEVIEN, R.; ZULPO, L.; BREZOLIN, D. Propriedades físicas do solo e crescimento de raízes de milho em um Argissolo Vermelho sob tráfego controlado de máquinas. Revista Brasileira de Ciência do Solo, v.37, p.1185-1195, 2013. DOI: 10.1590/S010006832013000500008.

MCHUGH, A.D.; TULLBERG, J.N.; FREEBAIRN, D.M. Controlled traffic farming restores soil structure. Soil and Tillage Research, v.104, p.164-172, 2009. DOI: 10.1016/j.still.2008.10.010.

MCPHEE, J.E.; AIRD, P.L.; HARDIE, M.A.; CORKREY, S.R. The effect of controlled traffic on soil physical properties and tillage requirements for vegetable production. Soil and Tillage Research, v.149, p.33-45, 2015. DOI: 10.1016/j.still.2014.12.018.

MORAES, M.T. de; DEBIASI, H.; CARLESSO, R.; FRANCHINI, J.C.; SILVA, V.R. da; LUZ, F.B. da. Age-hardening phenomena in an Oxisol from the subtropical region of Brazil. Soil and Tillage Research, v.170, p.27-37, 2017. DOI: 10.1016/j.still.2017.03.002.

MORAES, M.T. de; DEBIASI, H.; CARLESSO, R.; FRANCHINI, J.C.; SILVA, V.R. da; LUZ, F.B. da. Soil physical quality on tillage and cropping systems after two decades in the subtropical region of Brazil. Soil and Tillage Research, v.155, p.351-362, 2016a. DOI: 10.1016/j.still.2015.07.015.

MORAES, M.T. de; DEBIASI, H.; FRANCHINI, J.C.; SILVA, V.R. da. Benefícios das plantas de cobertura sobre as propriedades físicas do solo. In: TIECHER, T. (Org.). Manejo e conservação do solo e da água em pequenas propriedades rurais no sul do Brasil: práticas alternativas de manejo visando a conservação do solo e da água. Porto Alegre: Ed. da UFRGS, 2016b. p.34-48.

MORAES, M.T. de; DEBIASI, H.; FRANCHINI, J.C.; SILVA, V.R. da. Soil penetration resistance in a rhodic eutrudox affected by machinery traffic and soil water content. Engenharia Agrícola, v.33, p.748-757, 2013. DOI: 10.1590/S0100-69162013000400014.

MUNKHOLM, L.J.; HECK, R.J.; DEEN, B. Long-term rotation and tillage effects on soil structure and crop yield. Soil and Tillage Research, v.127, p.85-91, 2013. DOI: 10.1016/j.still.2012.02.007.

NOSALEWICZ, A.; LIPIEC, J. The effect of compacted soil layers on vertical root distribution and water uptake by wheat. 
Plant and Soil, v.375, p.229-240, 2014. DOI: 10.1007/s11104-0131961-0.

ORTIGARA, C.; MORAES, M.T. de; DEBIASI, H.; SILVA, V.R. da; FRANCHINI, J.C.; LUZ, F.B. da. Modeling of soil loadbearing capacity as a function of soil mechanical resistance to penetration. Revista Brasileira de Ciência do Solo, v.39, p.10361047, 2015. DOI: 10.1590/01000683rbcs20140732.

RICHARD, G.; COUSIN, I.; SILLON, J.F.; BRUAND, A.; GUÉRIF, J. Effect of compaction on the porosity of a silty soil: influence on unsaturated hydraulic properties. European Journal of Soil Science, v.52, p.49-58, 2001. DOI: 10.1046/j.13652389.2001.00357.x.

SANTOS, H.G. dos; JACOMINE, P.K.T.; ANJOS, L.H.C. dos; OLIVEIRA, V.A. de; LUMBRERAS, J.F.; COELHO, M.R.; ALMEIDA, J.A. de; CUNHA, T.J.F.; OLIVEIRA, J.B. de. Sistema brasileiro de classificação de solos. 3.ed. rev. e ampl. Brasília: Embrapa, 2013. 353p.

SINGH, A.; PHOGAT, V.K.; DAHIYA, R.; BATRA, S.D. Impact of long-term zero till wheat on soil physical properties and wheat productivity under rice-wheat cropping system. Soil and Tillage Research, v.140, p.98-105, 2014. DOI: 10.1016/j. still.2014.03.002.

TODMAN, L.C.; FRASER, F.C.; CORSTANJE, R.; DEEKS, L.K.; HARRIS, J.A.; PAWLETT, M.; RITZ, K.; WHITMORE, A.P. Defining and quantifying the resilience of responses to disturbance: a conceptual and modelling approach from soil science. Scientific Reports, v.6, art.28426, 2016. DOI: 10.1038/ srep28426.

TOLON BECERRA, A.; BOTTA, G.F.; LASTRA BRAVO, X.; TOURN, M.; MELCON, F.B.; VAZQUEZ, J.; RIVERO, D.; LINARES, P.; NARDON, G. Soil compaction distribution under tractor traffic in almond (Prunus amigdalus L.) orchard in Almería España. Soil and Tillage Research, v.107, p.49-56, 2010. DOI: 10.1016/j.still.2010.02.001.

TUlLBERG, J.N.; YULE, D.F.; MCGARRY, D. Controlled traffic farming-From research to adoption in Australia. Soil and Tillage Research, v.97, p.272-281, 2007. DOI: 10.1016/j. still.2007.09.007.

Received on January 30, 2017 and accepted on August 17, 2017 